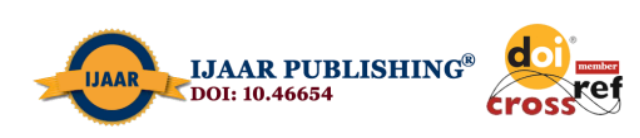

Research Journal of Management Practice | ISSN: 2782-7674

Vol. 1, Issue 4 (April, 2021) | www.ijaar.org

Journal DOI: www.doi.org/10.46654/RJMP

Article DOI: www.doi.org/10.46654/RJMP.1416

\title{
KNOWLEDGE MANAGEMENT AND FIRM INNOVATIVENESS OF MANUFACTURING FIRMS IN THE SOUTH-SOUTH OF NIGERIA
}

\author{
Agadah Mienipre $^{1}$ and Mrs. Christine A. Nwuche $(\mathrm{PhD})^{2}$ \\ ${ }^{1}$ Doctoral Candidate, Department of Management, University of Port Harcourt, Nigeria \\ ${ }^{2}$ Department of Management, University of Port Harcourt, Nigeria
}

\begin{abstract}
The purpose of this study was to investigate the relationship between knowledge management and firm innovativeness of manufacturing firms in the south-south of Nigeria. The study offers an empirical assessment of the relationship as based on its operational framework3bivariate null hypothetical statements are put forward. The research design adopted was the cross-sectional survey and data for this study was generated from managers and key personnel of the target organizations using structured questionnaire. The study adopted the Spearman's rank order correlation in its assessment for bivariate correlations between knowledge management and measures of firm innovativeness (propensity to create new products, propensity to create new business system and propensity to create new processes). The findings reveal significant relationships between knowledge management and the measures of firm innovativeness. In conclusion, it was stated that knowledge management, offers the necessary support, orientation and knowledge control for enhancing firm innovativeness.
\end{abstract}

Keywords: Firm Innovativeness, Knowledge Management, Propensity to create new products, Propensity to create new business system, Propensity to create new processes 


\section{Introduction}

Innovativeness helps businesses to deal with economic, consumer and customer demand shifts. And it has been one of organizations' most important and dynamic problems. It is recognized that being innovative is the key to securing any firm's future growth and survival (Tran, 2008). Bueno and Ordonez (2004) described innovation as a critical factor in the performance of firms and their survival in a competitive environment. Innovation is a key factor in the present dynamic and rapidly changing environment for all firms to survive and advance (Senge, 1990; Alegre \& Chiva, 2008).

A learning organization's concepts and dynamic capabilities draw attention to the fact that the context in which it takes place can facilitate or hinder organization. Knowledge can be obtained from outside sources or created with a company. Knowledge and reflection on the past performance of tasks is a source of information within an organization. All these mechanisms are fundamental aspects of organizational learning if they occur within a context (Ella \&Argote, 2011).

Companies attaining sustainable competitive advantage are challenging the competitive world of today (Dess, Lumpkin \& Eisner et al, 2002). Better and quicker learning competitions have only the strength and survival of companies (Sharifi \& Eslamiyeh, 2009). Guns (1996) stated that: "The function of today is the result of the learning of yesterday and the function of tomorrow is a consequence of the learning of today.' To put it another way, all the workers know affects the future of companies (Nekoei \& Beheshti, 2007). Organizational learning is a mechanism in which more things can be learned. Such learning signifies any changes in organizational models that may lead to the restoration or maintenance of organizational function (Alegra \& Chiva, 2008). Organizational learning is the ability to develop, acquire, transfer information and adapt and adjust organizational actions to represent new roles from an enhancement point of view of organizational operation (Jerez, Cespedes \& Valle, 2004). Templeton suggests that organizational learning is a set of organizational functions such as knowledge acquisition, the conscious and unconscious delivery and perception of information and memory with positive effects on organizational improvements (Templeton, Lewis \& Snyder, 2002).

Organizational learning capacity is defined as the organizational and managerial characteristics, activities, skills, and factors that promote organizational learning processes (e.g., information / knowledge production, acquisition, dissemination, and integration) and enable an organization to learn (Jarez, Cespedes \& Valle, 2005; Onaga, Tepecib \& Basalpc, 2014).

Learning skills are an important factor in an organization's further growth and innovation (Fang, Chang \& Chen, 2011). Organizational learning skills are a set of tools and/or tangible and intangible skills that are often required for competitive advantages (Bhatnagor, 2006).

Organizational preparation is the organization's secret to growth. It is because if the most effective organizations are met with weak learning skills, they will not benefit from all their strengths in today's complex environments. Therefore, only those firms are competitive in the near future which have consequently benefited from their maximum ability and learning potential of all workers at all levels of the company (Senge, 2009). To put it another way, more organizational learning capacity will result in better compatibility with changing environment. 
An organizational learning capacity is a sign of creating capacity and combining ideas in an effective way through managerial methods and innovations in contact with various organizational activities (Rashidi, Habibi \& Jafari, 2010). It is also regarded as an organization's managerial capacity for further production and the combination of important and effective ideas (Ulrich, Von \&Jick, 1993).

Gomez (2004) said that capacity for organizational learning plays a critical role in organizations' effectiveness and enhances their potential for innovation and growth. Tran (2008) concluded that some companies are more innovative because they focus more on learning. The need for creativity in the rapidly evolving world (Alegre \& Chiva, 2008) is one of the key reasons for the increasing value of organizational learning capacity over the past years.

Jerez, Cespedes and Valle (2005) consider that the potential for organizational learning is a key element in enhancing productivity and the ability of the business to develop and expand. Additionally, other scholars note that one of the key means of achieving long-term organizational success is organizational learning capacity (Liao \& Wu, 2010).

Several studies such as Nybakk, (2012), Tohidi and Mandegari (2012), Ferlin, (2007), and Onag, Tapeci and Basalp (2014) have extensively explored the issue of organizational learning as a method to enhance firm innovation. However, there is very little research in Nigeria that shows the relationship between knowledge management and innovativeness of companies. The aim of this study is to fill this gap in literature and explore the relationship between knowledge management and innovative firms in manufacturing firms in south-south Nigeria.

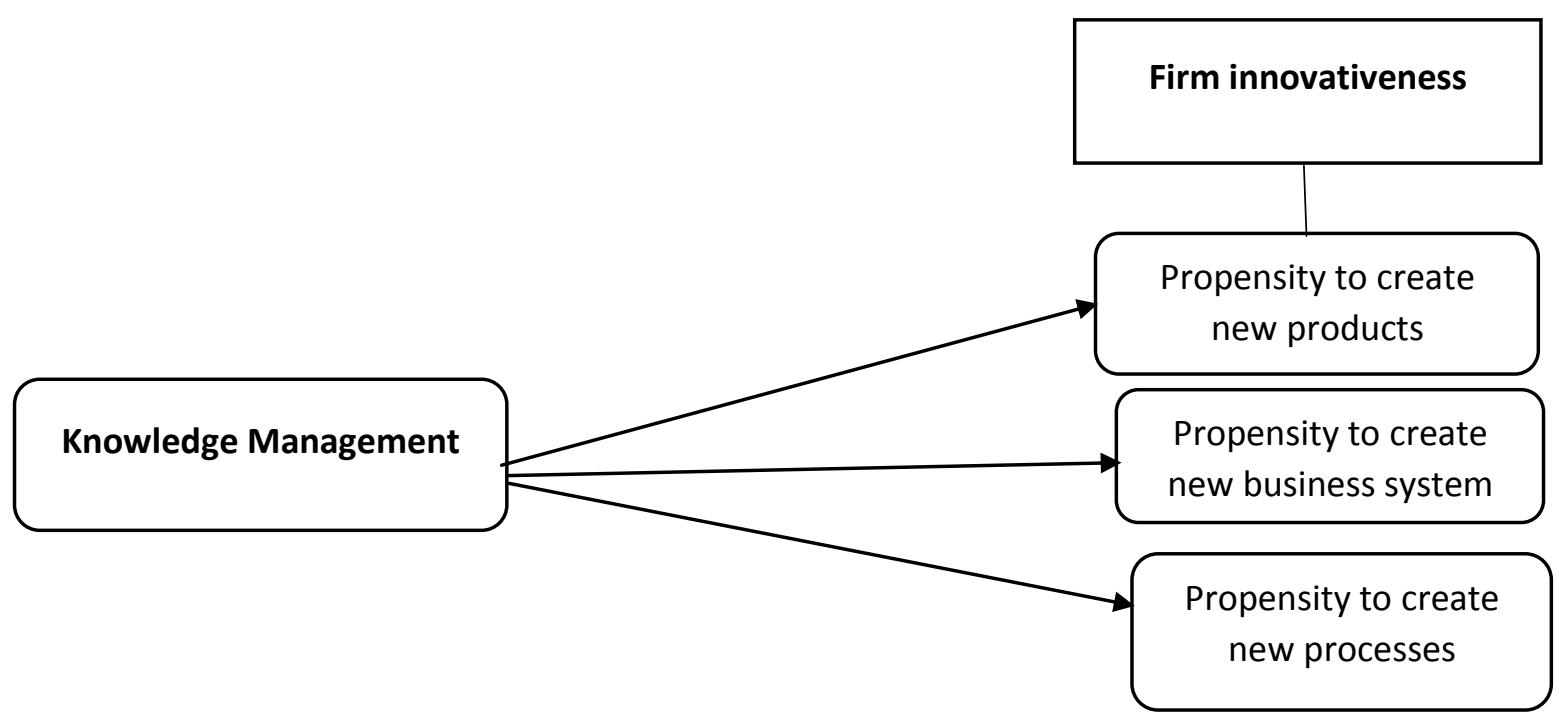

\section{Research Model}




\section{Aim and Objectives of the Study}

The aim of the study is to determine the relationship between knowledge management and firm innovativeness. Thus, the following specific objectives are stated as:

- To examine the relationship between knowledge management and propensity to create new products in manufacturing firms in South-South, Nigeria.

- To investigate the relationship between knowledge management and propensity to create new business system in manufacturing firms in South-South, Nigeria.

- To evaluate the relationship between knowledge management and propensity to create new processes in manufacturing firms in South-South, Nigeria

\section{Research Hypotheses}

Ho: There is no significant relationship between knowledge management and propensity to create new products in manufacturing firms in South-South, Nigeria.

$\mathbf{H}_{\mathbf{0 2}}$ : There is no significant relationship between knowledge management and propensity to create new business system in manufacturing firms in South-South, Nigeria.

$\mathbf{H}_{\mathbf{0 3}}$ : There is no significant relationship between knowledge management and propensity to create new processes

\section{Concept of Knowledge Management}

Knowledge management is the mechanism by which an organization's knowledge and information is developed, exchanged, used and managed (Girard, John \& Joann, 2015). Management of information is seen as a mechanism in which several processes are developed to carry out key elements of the knowledge management policy and operations of an organization. For example, an organization first needs to define and collect information, then coordinate it to put knowledge into the organizational boundaries. Knowledge is also transmitted and communicated by both human and technical means through the members of the organization. Through this transition, the company leaders may apply the new information to their tasks / work activities, which may include the use of knowledge management systems or the creation of the business case for knowledge management initiatives within a company.

Knowledge building and evolving is a significant and fundamental aspect of knowledge management (Dul, Ceylan, and Jaspers 2011; Nonaka 1991, 1994; Nonaka and Takeuchi 1995; Pan and Scarbrough 1999). Knowledge building is important for any organization's survival. The formation of awareness is an activity that takes place during everyday tasks, at work or in a social environment. The development of information occurs in several diverse ways, which may be by humanistic processes (such as formal training or talking to people with common interests) or scientific mechanisms (data mining). The creation of knowledge is primarily a human process; technology can facilitate the creation of knowledge but cannot replace humans. Organizations use new information to maximize their ability to construct awareness, evolve and create value. It is knowledge which leads to new and creative products; knowledge which improves internal processes and operations; or knowledge to enhance the organization's strategic decision-making ability and direction. According to 
Hislop (2013), the ability to generate knowledge and a competitive advantage is now essential for any organization that wishes to remain sustainable within its market.

\section{Concept of Propensity to create new products}

A "product" is an available good or service to the consumer or client (Barras, 1986). While product innovation is characterized as new products or services introduced to meet an external consumer or market need (Ettlie \& Reza, 1992; Knight, 1967; Untterback \& Abernathy, 1975).

Oslo Manual (2005) states that product innovation is the introduction of new or substantially enhanced products or services with respect to the characteristics of goods or services, it includes changes in technological requirements, components and materials, ease of use and the integration of software and other functional characteristics. According to Jonash \& Sommerlatte (1999), innovation in the product or service addresses the change, which allows for a competitive advantage, but in services. Innovativeness includes delivering a new service. Tiddel, Bessant and Pavitt (2005) report that product innovativeness is linked to changes in a company's products.

\section{Concept of Propensity to create new business system}

Innovativeness of the business system reflects a multitude of sales and marketing strategy practices an organization may use (Hovgaard\& Hansen, 2014). An example of an advancement in business systems is the introduction of a new framework for customer relationship management in a company's planning software system for enterprise resources. Innovativeness of the business system can apply to every aspect of the company that is needed to magnetize structure, operate and manage the business and its internal and external environment. Business systems innovation includes organizational innovations (defined as the creation or adoption of new ideas or behaviors for the organization) and the use of new management and work concepts and practices (Damanpour, 1987, 1996; Demanpour \& Evan, 1984).

The business method is "the 'job mechanism' (the production/delivery system) developed by a corporation to manufacture and distribute its products or services to its target consumers, both within and outside its boundaries." The business system is a reflection of the business architecture and how the organization mobilizes its capacities internally and organizes its activities. This also covers the division of labor between the company and its external trade partners and how this is handled. Companies like Wal-Mart and Dell have built a competitive edge by making improvements to their operations that saved money, improved customer service efficiency and increased sales and profits. At the one side, the business system always acts as a learning system. Examples such as Toyota or Google demonstrate that generating value and engaging with consumers, investors, and other stakeholders will contribute to more organizational learning and innovation (Itami \& Nishino, 2010).Furthermore, the business system consists of installing subsystems, processes and assets that are difficult to replicate and serve as barriers for competitors to imitate the business model (Teece, 2010)-e.g., taking the assets and skills needed to bring in a new pharmaceutical compound through clinical trials and evaluating its effectiveness in the treatment of specific diseases. However, on the other hand, the business system and the capital that is "frozen" within it may also constitute a barrier to changing an existing business model and make it difficult and time-consuming for incumbent firms to react with more effective business models to new entrants. 


\section{Concept of Propensity to create new processes}

A "process" means the way goods or services are generated and distributed (Barras, 1986). Process innovation is characterized as new elements incorporated into the manufacturing or service operations of an organization (e.g., input materials, job requirements, work and information flow processes and equipment) for producing a product or making a service (Ettie \& Reza, 1992; Knight, 1967; Utterback \& Abernathy, 1975).

Propensity to develop or implement new System focuses on enhancing production process quality and effectiveness (Higgins, 1995). This includes improvements in the production and distribution to consumers of goods and services (Tiddel, Bessant \& Pavitt, 2005).

Oslo Manuel (2005) defined process innovativeness as the introduction of a new method of production or delivery which has improved significantly. Important innovation that seeks to reduce cost of production or distribution to improve product quality and distribution (OECD, 2005).

\section{Theoretical framework}

\section{Knowledge - Based View}

The Knowledge-Based View (KBV) is an extension of the view of the resource. As a basis for competitive advantage, it advances the critical role of internal resources and focuses on differentiated knowledge inventories (Hoskisson et al., 1999). Information-based writers regard information as a strategic tool and knowledge collection as strategic capacity building (Conner, 1991; Grant, 1996; Kogut and Zander, 1993; Leonard-Barton, 1992; Liebaskind, 1996; Spender and Grant, 1996; Teece et al., 1997 and Winter, 1987).

Knowledge of routines and processes defining the distinctive way of doing things within the organization, and knowledge of customer needs and strengths of suppliers are critical for superior performance (Grant, 1991). A widely held view in the literature on strategic management is that disparities in performance between organizations are the product of their different information stocks and their varying knowledge creation and delivery capabilities (Choo and Bontis, 2002). The competitive world in which today's companies work has raised a great deal of interest in continuous learning and information gathering in organizations and being able to make informed timely decisions about the required improvement needed to sustain superior company efficiency (Sanchez, 1995).

\section{Empirical review}

Research managers at Hansen, Juslin and Knowles, (2007) describe a variety of essential characteristics of creative firms. Being innovative means creating or adopting something new and managers refer to new products, services and technology on a regular basis. The theme of creating the right culture or atmosphere conducive to innovation is dealt with in more detail later. Maintaining a close and practical link with the market is considered essential for being an innovative business. Managers consider innovators to be those companies that work proactively to stay ahead of the competition. Finally, creative companies are those that focus on the future and are capable of adapting to a changing world (Hansen, Juslin \& Knowles, 2007). As outlined above, creativity is something that is represented by company behavior and behaviors by managers from the specific study. 


\section{Methodology}

\section{Research Design}

This study adopted the cross-sectional survey as its research design for this study, in keeping with the above position. The survey can be used for descriptive and explorative purposes according to Babbie (2002). Sekaran and Bougie (2013) noted there are many advantages to the survey. In a given situation, it helps the researcher understand the characteristics of a variety of groups, cases or units.

\section{Population of the Study}

The research will be limited to all licensed manufacturing companies operating from the south-south in four states. There are thirty (30) registered manufacturing firms operating in Rivers / Bayelsa State, according to the "Manufacturers Association of Nigeria" (MAN), while thirty-five (35) registered manufacturing firms operating in Edo / Delta State constitute the target population. Nonetheless, because of the difficulty of performing a successful population survey, the researcher restricted the survey to an open population consisting of all registered chemicals and pharmaceutical manufacturing companies in Rivers, Bayelsa, Edo and Delta State. Data available from the Nigeria, Rivers, Bayelsa, Edo and Delta State Manufacturers Association revealed a total of nine (9) registered chemicals and pharmaceutical manufacturing companies registered with it. These companies have been selected based on industries that are closely related or of a competitive nature. Considering the product, it produces and its foundation of management.

Of the nine (9) selected firms, there are a total of one hundred and twenty (120) managers from Head of Departments to Managing Directors. In this study the sample size was determined using mathematical formula represented as follows:

$$
\begin{aligned}
& \mathrm{n}=\frac{\mathrm{N}}{1+\mathrm{N}(0.05)^{2}} \quad(\text { Taro Yamane Formular) } \\
& \text { Where } \mathrm{n} \quad=\quad \text { Sample size sought } \\
& \text { e }=\text { Level of significance } \\
& \mathrm{N}=\text { Target population size } \\
& \frac{120}{1+120(0.05)^{2}} \\
& \frac{120}{1+120(0.0025)^{2}} \\
& \frac{120}{1+0.3} \\
& \frac{120}{1.3} \\
& \mathrm{n}=\underline{\underline{92}}
\end{aligned}
$$




\section{Table 1 Population of Selected Manufacturing Firms}

$\mathbf{S} / \mathbf{N}$

NAME FOR FIRMS

Air Liquid Nig. Plc.

Notore

Chemicals

Industries

3.

Indorama

Petrochemical

4.

Cledop Chemical Manuf. Co. Ltd.

5.

6. Service Pharmaceutical Ind.

Ltd.

7. Nomagbon Services Ltd.

8. Esehi Pharmaceutical Ind.

Ltd.

9.

Pharmaceuticals Nig. Ltd.

\section{NUMBER \\ OF \\ MANAGERS}

18

14

18

14

31

24

11

8

7

5

9

7

8

6

8

6

10

8

120

The sample size for each firm was determined by using the Bowley's (1964) population allocation formula.

$\mathrm{nh}=\frac{\mathrm{nNh}}{\mathrm{N}}$

Where $\mathrm{nh}=$ Unit allocation for each firm

$$
\begin{array}{lll}
\mathrm{n} & = & \text { Total sample size } \\
\mathrm{Nh} & = & \text { Number of management staff in each firm } \\
\mathrm{N} & = & \text { Population size }
\end{array}
$$

For example the sample size of Notore Chemicals Industry

$$
\begin{array}{ll}
\mathrm{Nh} & =\frac{18 \times 92}{120} \\
= & 13.3 \\
= & \underline{\underline{14}}
\end{array}
$$




\section{Method of Data Analysis}

Demographic data were analyzed using descriptive statistics. Inferential statistics used the rank order correlation coefficient of the spearman - in evaluating the significance of the bivariate relationships. All hypotheses are reported at a confidence interval of 95 per cent, which means tests for the importance of relationships were based on a meaning level of 0.05

\section{Result and Discussions}

Survey activities involving the distribution of 92 copies of the questionnaire to the members of the target organizations. For most cases, Questionnaire administration was conducted directly including organizations close to the researcher as well as the use of research assistants to manage organizations far away from the researcher. A total of 92 copies of the questionnaire were distributed, and only 89 copies were recovered successfully.

Table 2: Relationship between Knowledge Management and Firm Innovativeness

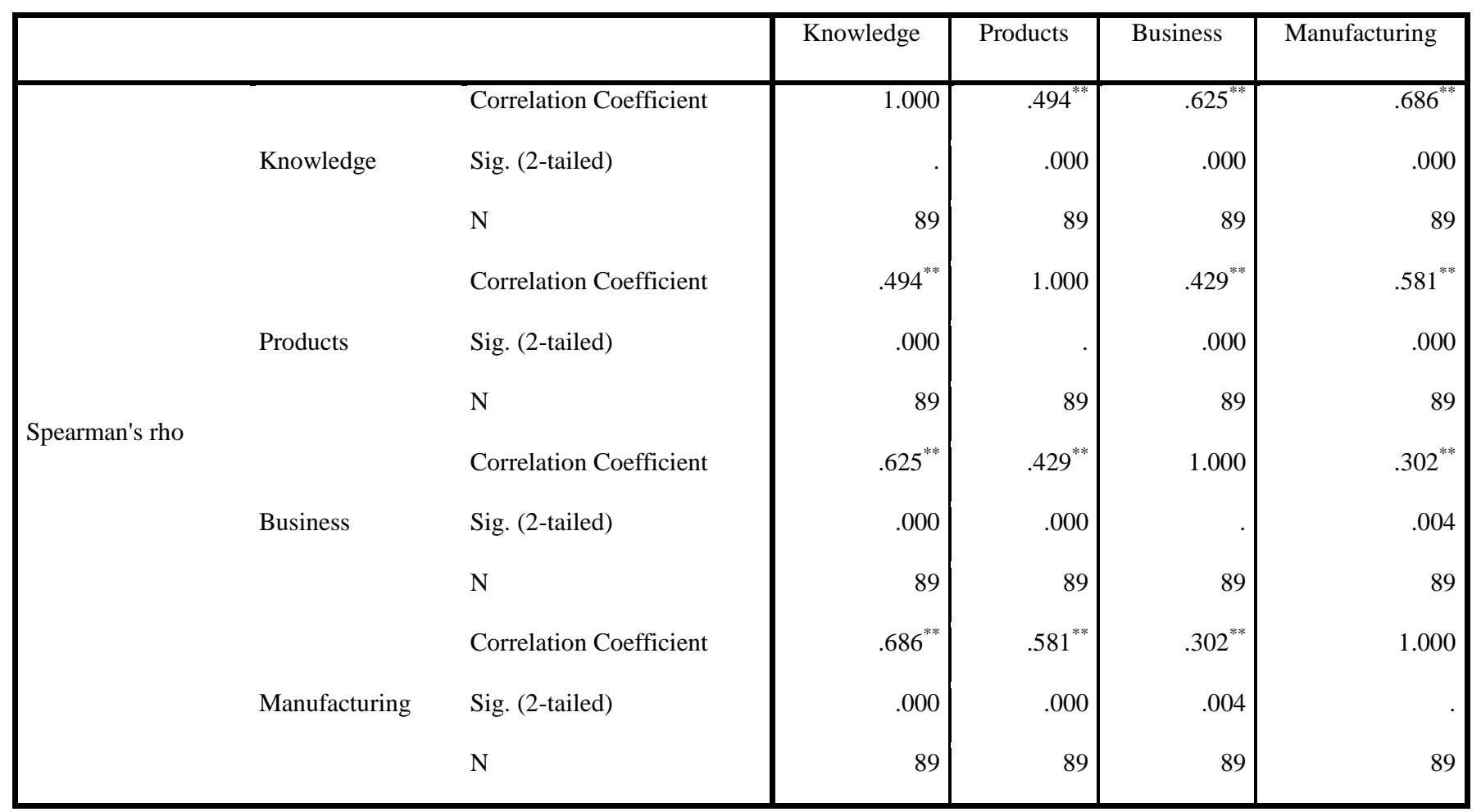

Source: Research survey, 2021

The result from the tests reveal as follows:

i. The relationship between knowledge management and the propensity to create new product is significant where rho $=0.494$ and $\mathrm{P}<0.05$. The result suggests that knowledge management has a positive impact on outcomes of propensity to create new product

ii. The relationship between knowledge management and the propensity to create new business system is significant where rho $=0.625$ and $\mathrm{P}<0.05$. The result suggests that knowledge management has a positive impact on outcomes of propensity to create new business system

iii. The relationship between knowledge management and the propensity to create new product is significant where rho $=0.686$ and $\mathrm{P}<0.05$. The result suggests that 
knowledge management has a positive impact on outcomes of propensity to create new manufacturing processes.

Based on the test results, it is clear that knowledge management is crucial to achieving outcomes such as the propensity to develop new product, the propensity to create new business structures and the propensity to create new production processes. On this note, all preceding null hypotheses are rejected as the result shows:

i. There is a significant relationship between knowledge management and propensity to create new products in manufacturing firms.

ii. There is a significant relationship between knowledge management and propensity to create new business systems in manufacturing firms.

iii. There is a significant relationship between knowledge management and propensity to create new manufacturing processes in manufacturing firms.

\section{Knowledge management and firm innovativeness}

The research also considers an important connection between knowledge management and company innovativeness. The evidence indicates the imperatives of gaining and exchanging information and the need for these in driving outcomes of propensity to create new goods, propensity to create new business structures, and propensity to create new production processes. One of the biggest concerns of organizations is maintaining and developing competitive advantage. There is now a strong emphasis on knowledge as a factor for success and innovation in the organization. If workers of a company resign or leave the organization for whatever cause, productivity in the organization is diminished.

As a result, companies are seeking to handle information more efficiently and more effectively to improve their efficiency (Salavati \& Haghnazar, 2010). The nature of the knowledge definition and the existence of multiple knowledge management methods are the explanation for the lack of a consistent attitude towards knowledge management. Management of information was researched according to several concepts (Yang, 2010). As a goal-oriented and structured method, knowledge management is defined as a tool for managing and monitoring the organizations' tangible and non-tangible information assets. This measure seeks to use existing internal and external knowledge of these organizations to generate new awareness, value development, innovation and advancement (Yang, 2004). From Bass's perspective, knowledge management is the process of knowledge creation, registration, refining, distribution and use (Oliveira, 2006).

Awareness comes from employee perspectives and skills. Any organization can create new definitions and meanings using various approaches to build and restructure current and prior information (Yaghoubi et al., 2011). The organizational measures of knowledge creation include: the importance of the value of knowledge creation, the presence of a suitable system for translating tacit knowledge into explicit knowledge, the extent of use of external information, encouragement of knowledge creation by the company, rewarding and promoting creativity by employees and new ideas; open conversation about the experiences and shortcomings of the organization, and the creation of organizational learning groups (Anvari-e-rostami et al., 2009).

Knowledge in the company should be open to everyone, so that it can be used at any time and location. New technologies like teamwork, the Internet, Intranet and other technologies will 
contribute to information sharing (Yaghoubi et al., 2011). Knowledge dissemination operational measures include: establishment of knowledge dissemination policies and procedures in the organization, use of Internet technology, office automation, teamwork and joint conferences, easy access to knowledge for all levels of employees, daily meetings for the sharing of information between employees, publication through the Internet of creative works by inventive workers, online magazines and so on (Anvari-e-rostami et al., 2009).

\section{Conclusion}

Knowledge management enhances management alignment and control so as to improve organizations' learning features and contribute positively to firm innovation outcomes such as the propensity to create new goods, the propensity to create new business structures and the propensity to create new processes

\section{Practical Implications}

The analysis of this study also advances practical implications for decision-making on the role of organizational leadership - particularly when it relates to their roles and support for learning and the advancement of knowledge. The findings point to the imperatives of promoting and endorsing leadership for learning processes and training or staff growth towards improving the organization's knowledge base. This illustrates the need for constructive leadership and commitment in finding prospects and skill growth.

The study further identifies the need for management to develop and advance their technical systems in a manner that suits the development and changes in their business or climate. This is as the evidence demonstrates the need for comprehensive and efficient technology programs to help and efficiently promote the organization's learning and information creation activities and functions. This role is focused on the technology's observed interrelated and integrative feature and its ability to drive communication and enhanced cooperation among organizational units, and also enhances coordination between the organization's leadership and junior members.

Therefore, organizations should adopt and institutionalize work structures and features that focus more on improving their learning ability, and advance these features or attributes through the adoption or implementation of technical systems that improve the organization's innovation and innovativeness. This study recognizes as crucial the role of leadership in the actualization of firm innovation and as such places importance on work processes and policies that encourage learning and developing skills and knowledge in a way that equips the company to deal effectively with the challenges and gaps in its market and climate. 


\section{References}

Alegre, J., \&Chiva, R. (2008). Assessing the impact of organizational learning capability on product innovation performance: An empirical test. Technovation, 28(6), 315-26.

Bueno E., \& Ordonez P., (2004). Innovation and learning in the knowledge-based economy challenges for the firm. International Journal of Technology and Management. 27(7): $531-533$

Choo, C.W. (2002). Knowledge management. In: J.R. Schement (Ed.) Encyclopedia of Communication and Information (pp. 501 -506). New York, NY: Macmillan Reference.

Dess, G.G. bumpkin, G.T., \& Eisner, A. (2002). Strategic management: Creating competitive advantages. MIT Sloan Management Review, 43(2), 34-41.

Dul, J., Ceylan, C. and Jaspers, F. (2011). Knowledge workers' creativity and the role of the physical work environment. Human Resource Management, 50(6), 715 - 734.

Fang, C.H., Chang, S.T., \& Chen, G.L. (2011). Organizational learning capability and organizational innovation: The moderating role of knowledge inertia. African Journal of Business Management,5(5), 1864-70.

Girard, John, P. \& Joann, L. (2005). "Defining knowledge and knowledge conversion: Controversy and Advancement in Organizational Knowledge Creation Theory" Organization Science. 20(3): 635 - 652.

Grant, R.M. (1991). The Resource Based Theory of Competitive Advantage. California Management Review. 33, 114 - 135.

Hansen, E., Juslin, H., \& Knowles, C. (2007). Innovativeness in the global forest products industry: exploring new insights. Can. J. For. Res. 37: 1324-1335.

Hovgaard, A.; \& Hansen, E. (2007). Innovativeness in the Products Industry. 54, 26 - 33.

Hoskisson, R.E., Hitt, M.A., Wan, W.P., \&Yiu, D. (1999). 'Theory and research in strategic management: swings of a pendulum', Journal of Management, 25(3), 417 - 456.

Itami, H., \& Nishino, K. (2010). Killing Two Birds with One Stone: Profit for Now and Learning for the Future. Long Range Planning, 43(2-3) 364-369.

Jerez-Gomez, P., Cespedes-Lorente, J. \& Valle-Cabrera, R. (2005). “Organizational learning and compensatioin strategies: evidence from the Spanish chemistry industry", Human Resource Management, 44(3): 297-299.

Liao, S.H. \& Wu, C.C. (2010). "System perspective of knowledge management, organizational learning and organizational innovation". Expert Systems with Applications, 37(2): 1096-1103.

NekoeiMoghaddam, M., \& Beheshti Far, M. (2007). Learning organizations. Tehran: Department of Resources and Management Development, Ministry of Health and Medical Education. 23.

OECD.(2005). Oslomanual: Guidelines for collecting and interpreting innovation data (3rded.). Luxembourg: OECD Publishing 
Onaga, A. O., Tepecib, M., \&Basalp, A. A. (2014). Organizational learning capability and its impact on firm innovativeness. Procedia - Social and Behavioral Sciences, 150: 708717.

Senge, P.M. (1990). The art and practice of the learning organization. The new paradigm in business: Emerging strategies for leadership and organizational change 126-138.

Sharifi, A., \&Eslamiyeh F. (2009). An investigation into the relationship between organizational learning andinformation and communication technology in Garmsar Islamic Azad University in the academic year 86-87. New Approaches in Educational Administration,1(2), 1-22.

Teece, D.J. (2010). Business models, business strategy and innovation. Long range planning, 43(2), $172-194$.

Templelon, G.F. Lewis, B.R., \& Snyder, C.A. (2002). Development of a measure for the organizational learning construct. Journal of Management Information Systems, 19(2), 175-218.

Tran, T., (2008). A conceptual model of learning culture and innovation schema. International Business Journal, 18(3), 287-299

Tidd, J., Bessant,J., \& Pavitt, K. (2005). Managing innovation: Integrating technological, market and organizational change ( $3^{\text {rd }}$ ed.). Chichester, West Sussex, England: John Wiley \& Sons., xviii, 582pp.

Ulrich, D.,,Von Glinow, M.A., \&Jick, T.D. (1993). High-impact learning: Building and diffusing learning capability. Organizational Dynamics.

Yang, C. C. (2012). Assessing the moderating effect of innovation capability on the relationship between logistics service capability and firm performance for ocean freight forwarders. International Journal of Logistics Research and Application. 15(1), 53-69. 